\title{
Improving the Effects of Omega-3 Fatty Acid on the In Vitro Maturation of Oocytes
}

\author{
Ghorbani Vahed $\mathrm{M}^{1,2}$, Khanbabaee $\mathrm{R}^{3^{*}}$, Shariati $\mathrm{M}^{4}$, Edalatmanesh $\mathrm{MA}^{2}$ \\ ${ }^{I}$ Department of Biology, Fars Science and Research Branch, Islamic Azad University, Fars, Iran \\ ${ }^{2}$ Department of Biology, Shiraz Branch, Islamic Azad University, Shiraz, Iran \\ ${ }^{3}$ Department of Biology, Qaemshahr Branch, Islamic Azad University, Qaemshahr, Iran \\ ${ }^{4}$ Department of Biology, Kazerun Branch, Islamic Azad University, Kazerun, Iran \\ *E-mail: khanbabaeeramazan@gmail.com
}

(received 27-08-2020; revised 28-10-2020; accepted 10-11-2020)

\begin{abstract}
ABSTRAK
Ghorbani Vahed M, Khanbabaee R, Shariati M, Edalatmanesh MA. 2020. Peningkatan pengaruh asam lemak omega-3 dalam pematangan oosit secara in vitro. JITV 25(4): 153-161. DOI:http://dx.doi.org/10.14334/jitv.v25i4.2555

Penelitian ini dilakukan untuk mengetahui pengaruh omega-3 terhadap pematangan oosit secara in vitro dan tingkat ekspresi tribbles (gen TRIB1, TRIB2 dan TRIB3) pada sel kumulus. Mencit NMRI berumur delapan-sepuluh minggu disuperovulasi menggunakan 7,5 IU serum gonadotropin (PMSG, Intraperitoneal) dari kuda bunting yang kemudian disembelih setelah 44 jam dan ovariumnya diangkat. Oosit digunakan untuk pematangan in vitro dan kompleks kumulus-oosit (COC) dilepaskan. Sel kumulus dan oosit dimasukkan ke dalam kontrol, dengan perlakuan etanol dan kelompok yang diberi 10 dan $100 \mu \mathrm{g} / \mathrm{ml} \mathrm{omega-3}$. Sel disiapkan guna melihat tahap pematangan untuk mengevaluasi tingkat ekspresi gen. Data dianalisis secara statistik. Mengekspos oosit dengan omega-3 dosis rendah $(10 \mu \mathrm{g} / \mathrm{ml})$ dan dosis tinggi (100 $\mu \mathrm{g} / \mathrm{ml})$ mengakibatkan penurunan laju oosit stadium GV, penurunan MI-oosit dan peningkatan MII-oosit. Peningkatan kematangan COC juga terdeteksi sebagai respon terhadap omega-3 dosis tinggi $(100 \mu \mathrm{g} / \mathrm{ml})$. Paparan sel kumulus terhadap omega-3 (10 dan $100 \mu \mathrm{g} / \mathrm{ml})$ menginduksi TRIB2 dan menghambat tingkat ekspresi gen TRIB3; namun, tingkat ekspresi gen TRIB1 meningkat dan menurun sebagai respon terhadap konsentrasi omega-3 yang rendah $(10 \mu \mathrm{g} / \mathrm{ml})$ dan tinggi $(100 \mu \mathrm{g} / \mathrm{ml})$. Penambahan omega-3 ke dalam lingkungan oosit atau sel kumulus mempengaruhi pematangan oosit dan sel kumulus, yang diikuti oleh ekspresi diferensial dari gen TRIB, menunjukkan peran metabolisme asam lemak dalam diferensiasi dan pematangan sel kumulus.
\end{abstract}

Kata Kunci: Sel Kumulus, Pematangan, Omega-3, Gen TRIB

\section{ABSTRACT}

Ghorbani Vahed M, Khanbabaee R, Shariati M, Edalatmanesh MA. 2020. Improving the effects of omega-3 fatty acid on the in vitro oocyte maturation. JITV 25(4): 153-161. DOI:http://dx.doi.org/10.14334/jitv.v25i4.2555

This research was conducted in order to determine the effects of omega-3 on oocyte in vitro maturation and the level of expression of tribbles (TRIB1, TRIB2 and TRIB3 genes) in cumulus cells. Eight-ten weeks old NMRI mice were super-ovulated using $7.5 \mathrm{IU}$ pregnant mare's serum gonadotropin (PMSG, Intraperitoneal) and they were killed after 44 hours and their ovaries were removed. The oocytes were used for in vitro maturation and the cumulus-oocyte complexes (COCs) were released. Cumulus cells and oocytes were assigned into control, ethanol-treated and groups exposed to 10 and $100 \mu \mathrm{g} / \mathrm{ml} \mathrm{of} \mathrm{omega-3.} \mathrm{The}$ cells were prepared to assess the maturation stage in order to evaluate the gene expression level. The data were statistically analyzed. Exposing oocytes to low dose $(10 \mu \mathrm{g} / \mathrm{ml})$ and high dose $(100 \mu \mathrm{g} / \mathrm{ml})$ of omega- 3 resulted in a reduced rate of GV-stage oocytes, decreased MI-oocytes and increased MII-oocytes. The enhanced maturity of COCs was also detected in response to a high dose of omega-3 $(100 \mu \mathrm{g} / \mathrm{ml})$. Exposure of cumulus cells to omega-3 $(10$ and $100 \mu \mathrm{g} / \mathrm{ml})$ induced TRIB2 and inhibited TRIB3 gene expression level; however, TRIB1 gene expression level increased and decreased in response to low $(10 \mu \mathrm{g} / \mathrm{ml})$ and high $(100 \mu \mathrm{g} / \mathrm{ml})$ concentrations of omega-3, respectively. The addition of omega- 3 to the environment of oocytes or cumulus cells affected the maturation of oocytes and cumulus cells, which was followed by the differential expression of TRIB genes, suggesting that there was a role of fatty acid metabolism in the differentiation and maturation of cumulus cells.

Key Words: Cumulus Cells, Maturation, Omega-3, Oocyte, TRIB Genes

\section{INTRODUCTION}

There are many clinical and experimental data demonstrating the health benefits of omega-3 fatty acids in healthy individuals as well as patients with reproductive failures (Jeromson et al. 2015; Cao et al. 2015). In vivo and in vitro studies represent that many aspects of reproductive system, including oogenesis and spermatogenesis, are influenced by omega-3 fatty acids metabolism (Nehra et al. 2012; Gulliver et al. 2012; 
Meher et al. 2013). Omega-3 fatty acids have also a significant role in oocyte maturation as well as oocyte quality (Chiu et al. 2018; Ortiz et al. 2014). In vivo experiments have shown that intake of foods and supplements containing omega- 3 acids contributes to granulosa cells and oocytes growth and development (Wonnacott et al. 2020). Since ovarian compartments are composed of fatty acids, dietary n-3 fatty acids can modify the ovarian compartments, resulting in improved ovarian structure and function (Zachut et al. 2010). Polyunsaturated fatty acids are major components of the granulosa cells surrounding oocytes and contribute to oocytes maturation and therefore play significant role in female fertility (Khalil et al. 2013; Shaaker et al. 2012). In this condition, in vitro studies have indicated that during oocyte maturation, unsaturated lipids are incorporated into the oocyte cytoplasm and influence cellular metabolism and oocyte growth and development (Carro et al. 2013).

Fatty acids involved in maturation of oocytes can regulate expression level of genes associated with oocyte maturation (Veshkini et al. 2016; Virant-Klun et al. 2013). Recently, certain gene expression profiles have been studied and the findings indicate that oocyte maturation and follicular growth involve the expression of a number of genes including Tribbles (TRIB) genes (Hernández-Montiel et al. 2019; Lussier et al. 2017; Brisard et al. 2014). However, TRIB genes have been less studied and the modulation of their expression during oocyte maturation is somehow unclear. The association of Tribbles, TRIB1, TRIB2 and TRIB3, with fatty acid metabolism has also been demonstrated in several studies. The findings indicate that Tribbles regulate cell proliferation in many tissues partly due to their impact on fatty acid metabolism (Lohan \& Keeshan 2013). TRIB1 has been reported to promote lipid metabolism in human tissues (Legault et al. 2018). However, TRIB3 prevents fat accumulation in adipocytes (Örd et al. 2015; Lirangi et al. 2012). The association of in vivo oocyte maturation and TRIBI gene expression level has been reported (Brisard et al. 2014). TRIB2 gene expression level is also changed in granulosa and cumulus cells during oocyte development (Lussier et al. 2017; Assidi et al. 2010).

Altogether, these observations hypothesized and somehow revealed that omega-3 fatty acids may influence in vitro oocyte maturation as a microenvironment. Fatty acids also can alter expression level of Tribbles in follicular cells. However, there are not sufficient findings clearly showing the association of omega-3 fatty acids with Tribbles expression level alteration during oocyte maturation. In this condition, the purpose of this research was to determine the effects of omega-3 on oocyte maturation in vitro and expression level of Tribbles (TRIB1, TRIB2 and TRIB3 genes) in cumulus cells surrounding oocytes.

\section{MATERIALS AND METHODS}

\section{Chemicals and reagents}

Omega-3-acid ethyl esters capsules were purchased from Pronova Biopharma Norway Pharmacy Company. Ethanol (96\%) (as solvent) was added to content of each capsule to prepare the desired solution.

\section{Collection of oocytes}

This experimental study was conducted on 100 female NMRI mice, aged 8-10 weeks that were maintained on a 12-12 h light-dark schedule with ad libitum access to food and water. According to previous studies (Sirard 2011; Nikseresht 2015) animals were super-ovulated by an intraperitoneal injection of $7.5 \mathrm{IU}$ pregnant mare serum gonadotrophin [PMSG Intervet, UK]. Ether was used to anesthetize the animals and the ovaries were removed into TCM-199 [Sigma] supplemented with $10 \%$ fetal bovine serum (FBS). The ovaries were punctured and cumulus-oocyte complexes (COCs) were released under a stereomicroscope. Oocytes were used for in vitro maturation. The study protocol was approved by the ethics committee of Islamic Azad University, Shiraz, Iran (Ethical no: IR.IAU.SHIRAZ.16330641322009).

\section{In vitro maturation (IVM)}

The oocytes and cumulus cells were cultured in $\alpha$ MEN culture medium containing 5\% FBS, $0.1 \mathrm{IU} / \mathrm{mL}$, LH rh FSH, 7.5 IU/mL and 1\% Penicillin-Streptomycin. The cells were assigned into 4 groups: Control (no treatment), Ethanol treated (exposed to ethanol 96\%), Experimental 1 and Experimental 2 (exposed to 10 and $100 \mu \mathrm{g} / \mathrm{ml}$ of omega-3 fatty acid, respectively). The cells were incubated for $24 \mathrm{~h}$ at $38.58^{\circ} \mathrm{C}$ under $5 \% \mathrm{CO}_{2}$ in humidified air and prepared for determination of maturation stage and evaluation of gene expression level in cumulus cells.

\section{Assessment of oocyte maturation rate}

Oocytes were stripped from cumulus cells by repetitive aspiration-ejection using a Gilson pipette and then immediately fixed in $4 \%$ paraformaldehyde phosphate buffered saline (PBS) solution at room temperature for 30 minutes. Hoechst $33342(0.1 \%$ in PBS) was used for incubating fixed oocytes for 10 minutes and mounted on a glass slide in Mowiol solution. The maturation quality of oocytes was determined according to previous studies (Brisard et al. 2014). In the case of seeing the telophase-I or metaphase-II stage, the oocytes were considered mature. As a percentage of mature oocyte in a total 
Table 1. Specific primers for TRIB1, TRIB2 and TRIB3 genes

\begin{tabular}{lccc}
\hline \hline \multirow{2}{*}{ Genes } & \multicolumn{3}{c}{ Parameters } \\
\cline { 2 - 4 } & Sequence $\left(5^{\prime}->3^{\prime}\right)$ & Annealing $\left({ }^{\circ} \mathrm{C}\right)$ & Product Size $(\mathrm{bp})$ \\
\hline Trib1-F & CCTCGAATATGGCAGCATTT & 101 \\
Trib1-R & CGAGTCTCCTCACCCTTGTC & 60 & \\
Trib2-F & TTGGAACAGACCAACCACCT & 68 \\
Trib2-R & TTTAGCACCCAGGTTTCAGG & 60 & \\
Trib3-F & GGAACCTTCAGAGCGACTTG & & \\
Trib3-R & TCTCCCTTCGGTCAGACTGT & 60 & \\
Rplp0-F & TGCCACACTCCATCATCAAT & & 97 \\
Rplp0-R & AGGAAGGCCTTGACCTTTTC & 60 & \\
\hline
\end{tabular}

F: Forward, R: Reverse

number of live oocytes, the maturation rate was calculated.

\section{Evaluation of Tribble expression level}

Cumulus cells of COCs at maturation state were seeded in dishes. Twentyfour hours after seeding, the cells were incubated with the ethanol and omega-3 (10 and $100 \mu \mathrm{g} / \mathrm{ml}$ ) for $12 \mathrm{~h}$. Cells were then centrifuged and washed with ice-cold PBS. Total RNA was extracted using a RNeasy midi kit [Roche, 1828 665, Germany] and reverse transcribed into cDNA using a Transcriptor First Strand cDNA synthesis kit [Roche,04 379012 001, Germany]. Quantitative Real-Time PCR (LightCycler-FastStart DNA master SYBR Green I Kit [ABI, 4369016, American] and Light Cycler apparatus [Roche Diagnostics]) was carried out to evaluate the expression level of TRIB1, TRIB2 and TRIB3 genes using the specific primers (Table 1). RT-PCR reaction was conducted during a program at a temperature of $95^{\circ}$ $\mathrm{C}$ for 15 minutes and was subjected to 40 cycles compose of three-steps program at $95^{\circ} \mathrm{C}$ for 10 second, at $60^{\circ} \mathrm{C}$ for 30 second and at $72^{\circ} \mathrm{C}$ for 30 second. $R p l p 0$ gene (as reference gene) was used to normalize the relative expression for interested genes calculated by $2^{-\Delta \Delta \mathrm{CT}}$ method. An agarose gel electrophoresis was used to confirm the expected PCR products.

\section{Data analysis}

Results are expressed as mean \pm SD. Statistical analysis was performed using one-way analysis of variance (ANOVA method) followed by post hoc Tukey's multiple comparisons test in SPSS 20 software. Differences were considered significant at the $\mathrm{P}<0.05$ level.

\section{RESULTS AND DISCUSSION}

\section{Result}

\section{Maturation status of oocytes}

Oocytes were examined in control, ethanol treated and experimental groups at $24 \mathrm{~h}$ of IVM. Table 2 indicates the status of oocytes in control and ethanol treated groups and groups exposed to 10 and $100 \mu \mathrm{g} / \mathrm{ml}$ of omega-3 at 24 hours of IVM. Exposure of oocytes to $10 \mu \mathrm{g} / \mathrm{ml}$ of omega- 3 resulted in lower degenerated oocytes and to $100 \mu \mathrm{g} / \mathrm{ml}$ of omega-3 led to higher degenerated oocytes compared with control group. The rate of GV-stage oocytes was significantly lower in groups exposed to 10 and $100 \mu \mathrm{g} / \mathrm{ml}$ of omega- 3 than control group. Adding omega-3 (10 and $100 \mu \mathrm{g} / \mathrm{ml})$ to live oocytes environment resulted in significant decrease in oocytes arrested at MI stage and significant increase in the rate of oocytes arrested at MII stage compared to control group.

\section{Maturation status in COCs}

Complete maturation was also examined in preovulatory COCs in control, ethanol treated and experimental groups $34-38 \mathrm{~h}$ after triggering ovulation. 
COCs were graded by observational evaluation of morphological features such as the thickness and compactness of the cumulus cells and ooplasm homogeneity. According to previous studies, based on light microscopy, COCs surrounded by several layers of cumulus cells and with evenly granulated ooplasm were considered to have higher developmental competence in vitro (complete maturation) than oocytes with irregularly granulated ooplasm and fewer cumulus layers (Gumus et al. 2010).

Reduced maturity was observed in COCs exposed to $10 \mu \mathrm{g} / \mathrm{ml}$ of omega-3; however, exposure of COCs to $100 \mu \mathrm{g} / \mathrm{ml}$ of omega- 3 led to an increased maturity rate (Figure 1). The rate of COCs at MII stage risen significantly in the group exposed to $10 \mu \mathrm{g} / \mathrm{ml}$ of omega-3. However, adding $100 \mu \mathrm{g} / \mathrm{ml}$ of omega-3 to COCs environment resulted in decreased COCs at MII stage. GV/MI rate in COCs was significantly lower in the group exposed to $10 \mu \mathrm{g} / \mathrm{ml}$ of omega-3 and was considerably higher in the group exposed to $100 \mu \mathrm{g} / \mathrm{ml}$ of omega-3 compared with control group (Figure 2).

\section{TRIB genes expression level in cumulus cells}

TRIB1, TRIB2 and TRIB3 genes expression level was evaluated in cumulus cells of COCs at complete maturation stage (Table 3). Exposure of COCs to 10 $\mu \mathrm{g} / \mathrm{ml}$ of omega-3 resulted in reduced expression level of TRIBI gene and exposure to $100 \mu \mathrm{g} / \mathrm{ml}$ of omega-3 led to significant increase in TRIBI gene expression level. TRIB2 gene expression level significantly increased in groups exposed to 10 and $100 \mu \mathrm{g} / \mathrm{ml}$ of omega-3, however, the expression level was higher in the group exposed to $10 \mu \mathrm{g} / \mathrm{ml}$ of omega- 3 than the group exposed to $100 \mu \mathrm{g} / \mathrm{ml}$ of omega-3. TRIB3 gene expression level significantly decreased in groups exposed to 10 and $100 \mu \mathrm{g} / \mathrm{ml}$ of omega-3. We did not observe significant difference between ethanol treated and control groups in our experiments, indicating that ethanol (as solvent) did not have significant impact on the research data

\section{Discussion}

Our findings indicated that exposure of live oocytes to low $(10 \mu \mathrm{g} / \mathrm{ml})$ and high $(100 \mu \mathrm{g} / \mathrm{ml})$ dose of omega3 -acid ethyl ester resulted in reduced rate of $\mathrm{GV}$-stage oocytes, decreased MI-oocytes and increased MIIoocytes, demonstrating the stimulatory effects of omega-3 on maturation of live oocytes in vitro. In addition, our results have revealed that adding the low $(10 \mu \mathrm{g} / \mathrm{ml})$ and high $(100 \mu \mathrm{g} / \mathrm{ml})$ dose of omega-3 to COCs environment increased and decreased maturity of COCs, respectively.

In line with our findings numerous studies have reported that unsaturated fatty acids and omega-3 derivatives play significant role in maturation of oocytes and granulosa cells in various species. Indeed, long-chain poly unsaturated fatty acids such as omega-3 and omega- 6 are integral component of the membrane lipid bilayer in many types of cells, including reproductive system cells (Gulliver et al. 2012), by which may influence cell function and development. Studies have shown that the dietary supplementation of omega-3 can improve reproductive system function in different species (Kirkup et al. 2010; Safdar et al. 2017). A large body of experimental research has also demonstrated that omega-3 improves female reproductive system function by affecting on female hormones precursors and the genes associated with oogenesis (Gulliver et al. 2012; Cheng et al. 2013; Dirandeh et al. 2015). Dietary n-3 fatty acids have been reported to influence the follicular status and to increase the cleavage rate of oocytes (Zachut et al. 2010). In vivo investigations on oocyte and embryo development have revealed that regular intake of unsaturated fatty acids has improving effects on oocyte maturation and embryo development (Fayezi et al. 2018). Fatty acids can also modulate granulosa cell proliferation and steroidogenesis in vitro (Maillard et al. 2018), by which may influence cumulus-oocyte complexes (COCs) maturation. The data obtained in recent studies confirm the significant association of unsaturated fatty acids with oocyte maturation and implantation (Mirabi et al. 2017; Oseikria et al. 2016; Mahla et al. 2017).

The cytotoxic and genotoxic effects of unsaturated fatty acids on oocytes and cumulus cells during IVM have been investigated (Nikoloff et al. 2017). The previous studies have suggested that the effect of fatty acids on in vitro systems depends in part on the concentration of unsaturated fatty acids and the cell type used in the study (Meng et al. 2013; Zajdel et al. 2013). The use of low concentrations of unsaturated fatty acids such as eicosapentaenoic acid can improve oocyte quality and cumulus expansion, while its high concentrations can induce cytotoxic and genotoxic effects. In the present study, the use of low dose of omega-3 decreased degenerative oocytes and the high dose of omega-3 increased degenerated oocytes, which is consistent with the previous studies (Nikoloff et al. 2017). The relationship between oocytes and cumulus cells is established through a gap junction so that any change made in these cells reduces the quality of oocytes (Zhou et al. 2016). It has been observed that high concentrations of unsaturated fatty acids such as eicosapentaenoic acid can induce apoptosis in cumulus cells. Also, the cytotoxic effects of unsaturated fatty acids at high concentrations can be associated with decreased metabolic activity and decreased mitochondrial activity. The increase in degenerative oocytes in this study can be explained by this possible mechanism that unsaturated fatty acids at high concentrations may be suitable targets for the formation 
Table 2. Effect of ethanol and omega-3 on the in vitro maturation of oocytes in mice

\begin{tabular}{|c|c|c|c|c|}
\hline \multirow[b]{2}{*}{ Parameters } & \multicolumn{3}{|c|}{ Groups } & \multirow[b]{2}{*}{$\begin{array}{c}\text { Exp2 } \\
(100 \mu \mathrm{g} / \mathrm{ml})\end{array}$} \\
\hline & Control & Ethanol-treated & $\begin{array}{c}\text { Exp1 } \\
(10 \mu \mathrm{g} / \mathrm{ml})\end{array}$ & \\
\hline Degenerated (\%) & 7.6 & $8.6^{\mathrm{ns}}$ & $5.8^{1, *}$ & $10.8^{1, * * ; 2, *}$ \\
\hline $\mathrm{GV}(\%)$ & 13 & $11.8^{\mathrm{ns}}$ & $5^{1, * * *}$ & $8.1^{1, * * ; 2, *}$ \\
\hline Metaphase I (\%) & 15.2 & $14^{\mathrm{ns}}$ & $7.9^{1, * * *}$ & $3.6^{1, * * * ; 2, *}$ \\
\hline Metaphase II (\%) & 64.2 & $65.6^{\mathrm{ns}}$ & $81.3^{1, * * *}$ & $77.5^{1, * * * ; 2, *}$ \\
\hline Number of oocytes & 150 & 150 & 150 & 150 \\
\hline
\end{tabular}

$\overline{\mathrm{GV}}$ : arrested at germinal vesicle state (nucleus of oocyte is arrested in prophase of meiosis I)

${ }^{1}$ and ${ }^{2}$ indicate significant difference compared with control and group exposed to $10 \mu \mathrm{g} / \mathrm{ml}$ of omega-3 at $24 \mathrm{~h}$ of IVM, respectively; ns: indicates non-significant difference. ${ }^{*}: \mathrm{P} \leq 0.05,{ }^{* *}: \mathrm{P} \leq 0.01,{ }^{* * *}: \mathrm{P} \leq 0.001$

Table 3. Effect of ethanol and omega-3 on the relative gene expression level (RQ) of TRIB1, TRIB2 and TRIB3 in cumulus cells

\begin{tabular}{lcccc}
\hline \hline & \multicolumn{3}{c}{ Groups } \\
\cline { 2 - 5 } Genes & Control & Ethanol-treated & $\begin{array}{c}\text { Exp1 } \\
(10 \mu \mathrm{g} / \mathrm{ml})\end{array}$ & $\begin{array}{c}\text { Exp2 } \\
(100 \mu \mathrm{g} / \mathrm{ml})\end{array}$ \\
\hline TRIB1 & $1.03 \pm 0.02$ & $1.14 \pm 0.08^{\mathrm{ns}}$ & $4.28 \pm 0.22^{1, * *}$ & $0.38 \pm 0.03^{1, * * * 2, * * *}$ \\
TRIB2 & $0.38 \pm 0.02$ & $0.44 \pm 0.01^{\mathrm{ns}}$ & $4.85 \pm 0.24^{1, * *}$ & $2.36 \pm 0.04^{1, * * ; 2,}$ \\
TRIB3 & $2.30 \pm 0.21$ & $1.94 \pm 0.41^{\mathrm{ns}}$ & $1.55 \pm 0.32^{1, * *}$ & $0.76 \pm 0.06^{1, * * ; 2,}$ \\
\hline
\end{tabular}

Data represents relative gene expression (Target/Rplp0) mean \pm SEM of three experiments $(n=3) .{ }^{1}$ and $^{2}$ indicate significant difference compared with control and group exposed to $10 \mu \mathrm{g} / \mathrm{ml}$ of omega-3, respectively; ns: indicates non-significant difference, ${ }^{* * *}: \mathrm{P} \leq 0.01,{ }^{* * * *}: \mathrm{P} \leq 0.001$

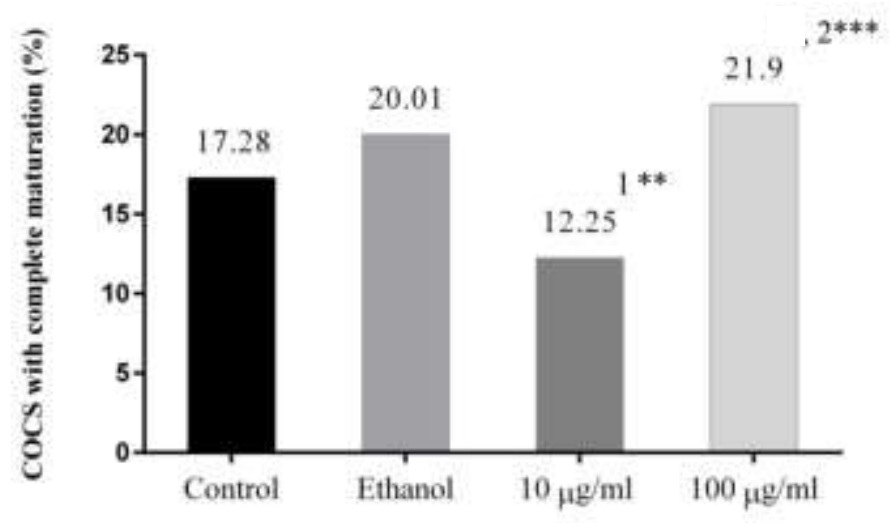

Figure 1. Complete maturation in control, ethanol treated COCs and COCs exposed to 10 and $100 \mu \mathrm{g} / \mathrm{ml}$ of omega-3 at GV/MI stage. ${ }^{1}$ and ${ }^{2}$ indicate significant difference compared with control group and group exposed to $10 \mu \mathrm{g} / \mathrm{ml}$ of omega- -3 , respectively $\left({ }^{*}: \mathrm{P} \leq 0.05,{ }^{* *}\right.$ : $\left.\mathrm{P} \leq 0.01,{ }^{* * *}: \mathrm{P} \leq 0.001\right)$. 


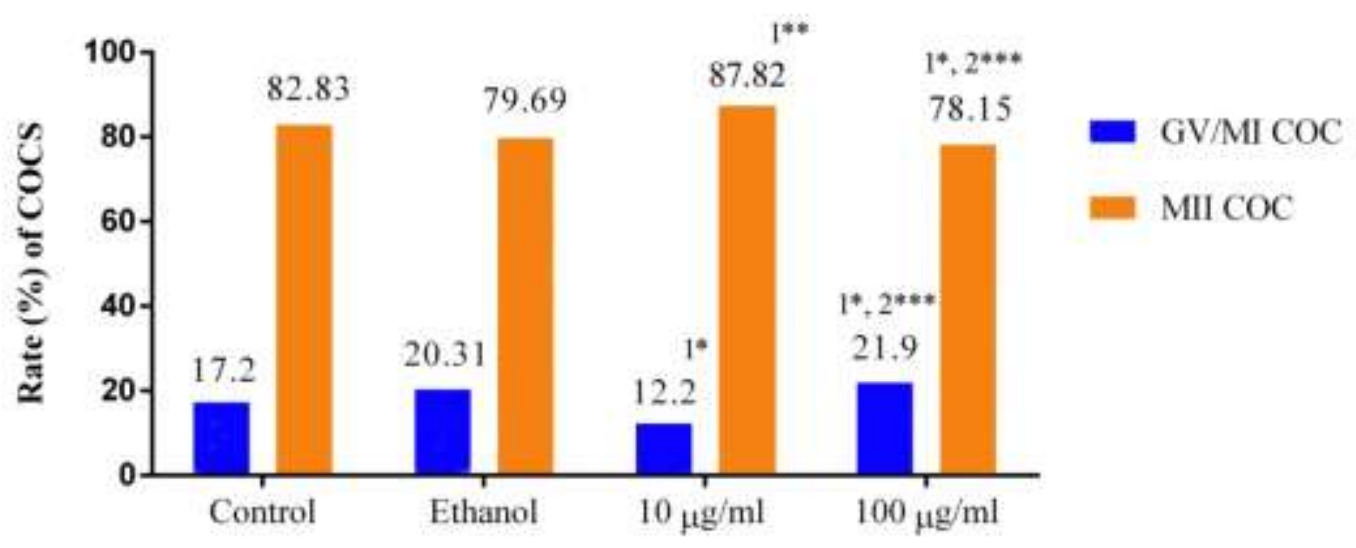

Figure 2. The rate (\%) of COCs at GV/MI and MII stages in control and ethanol treated groups and groups exposed to 10 and $100 \mu \mathrm{g} / \mathrm{ml}$ of omega-3. ${ }^{1}$ and ${ }^{2}$ indicate significant difference compared with control group and group exposed to $10 \mu \mathrm{g} / \mathrm{ml}$ of omega-3, respectively $\left({ }^{*}: \mathrm{P} \leq 0.05,{ }^{* *}: \mathrm{P} \leq 0.01,{ }^{* * *}: \mathrm{P} \leq 0.001\right)$.

of free radicals. The formation of free radicals after long-chain peroxidation of unsaturated fatty acids can be the main cause of damage to DNA and proteins, resulting in reduced quality and maturation of oocytes (Nikoloff et al. 2017). Therefore, based on the findings of this study, it seems that the high dose of omega-3 has destructive effects on oocyte maturation.

In the present study we found that exposure of COCs to low dose of omega-3 resulted in increased maturation and to high dose of omega- 3 led to decreased maturity of COCs. The findings of a recent study have shown that the maturation parameters of COCs were affected by exposure of COCs to different eicosapentaenoic acid concentrations in the IVM medium and higher and lower concentrations of eicosapentaenoic acid have different impacts on COCs maturation (Nikoloff et al. 2017). In contrast to our findings, there are research showing that fatty acids may retard growth and development in oocytes. It has been reported that the exposure of oocytes to an environment high in omega-3 fatty acids led to decreased developmental ability of the blastocyst stage (Dunning et al. 2010). Adding alpha-linolenic fatty acids to oocyte environment also has been shown to increase reactive oxygen species levels, which mediate, at least in part, the inhibitory effect on oocyte maturation (Marei et al. 2012). Higher levels of saturated fatty acids, especially palmitic and stearic acids, were observed in some metabolic contexts to have harmful effects on oocyte maturation (Mirabi et al. 2017).

Results of this study indicated that adding omega-3 (10 and $100 \mu \mathrm{g} / \mathrm{ml}$ ) to COCs environment induced TRIB2 and inhibited TRIB3 gene expression in cumulus cells. However, TRIB1 gene expression level increased and decreased in response to low $(10 \mu \mathrm{g} / \mathrm{ml})$ and high $(100 \mu \mathrm{g} / \mathrm{ml})$ concentrations of omega-3, respectively. In line with this findings a research carried out to evaluate
$T R I B$ genes expression level in pre-ovulatory follicles indicated that TRIB1, TRIB2 and TRIB3 are expressed in different patterns in cumulus cells surrounding the oocytes from pre-ovulatory follicles (Brisard et al. 2014), and therefore, it is expectable that adding different doses of omega- 3 fatty acids to cumulus cells has different effects on TRIB genes expression level. Previous studies also have revealed a significant relationship between TRIB genes expression level and fatty acid metabolism in cumulus cells during oocyte maturation. It has been shown that TRIB genes are involved in the cell-cycle progression during cell division (Dugast et al. 2012), which is accompanied by an increase in cellular metabolism rate including fatty acids metabolism. Indeed, maturation process is associated with significant change in COCs lipid metabolism which at least in part is regulated by TRIB genes expression (Bauer et al. 2015). A link between TRIB1 gene expression level and lipid metabolism has been reported in recent studies (Wang et al. 2015). The findings show that the expression level of TRIB3 has significant impact on carbohydrate metabolism (Zhang et al. 2016), which in turn, may influence lipid metabolism as well. Although the findings of our research indicated that adding omega-3 to COCs environment upregulates TRIB2 and downregulates $T R I B 3$ in cumulus cells, it has been previously shown that TRIB3 was up-regulated and TRIB2 was downregulated during the preovulatory period in cumulus cells (Lussier et al. 2017).

The studies indicate that all the three TRIB genes are regulated differently at different times in response to the inhibition of fatty acid peroxidation. This confirms that the three TRIB genes are involved in fatty acids metabolism and cumulus cells proliferation and play a key role in the resumption of meiosis and oocyte maturation (Brisard et al. 2014). 
In this study, increased expression of TRIBI and TRIB2 and decreased expression of TRIB3 is associated with increased maturation of the COCs at low dose (10 $\mu \mathrm{g} / \mathrm{ml}$ ) of omega- 3 , however, at the maximum dose $(100 \mu \mathrm{g} / \mathrm{ml})$ of omega- 3 , the expression level of the TRIB genes were significantly reduced compared to the low dose $(10 \mu \mathrm{g} / \mathrm{ml})$ group of omega-3. Based on these findings, omega-3 appears to have a dose-dependent effect on gene expression and maturation of the COCs. Because a few studies are available on the effects of TRIB genes expression on the COCs, and the effects of omega-3 on different genes are variable, reducing the expression of TRIBI at the maximum dose $(100 \mu \mathrm{g} / \mathrm{ml})$ of omega-3 could be due to the cytotoxic effects of omega-3 at high doses in the form of impaired metabolic activity and the formation of free radicals due to peroxidation of fatty acids (Wu et al. 2015). Decrease in TRIB1 gene expression at the high dose $(100 \mu \mathrm{g} / \mathrm{ml})$ of omega-3 can also be attributed to an increase in COCs at the GV/MI stage, so that the decrease of oocytes at GV/MI stage is associated with an increase in TRIB1 expression and its increase is associated with decreased TRIBI expression in this study.

Our study only investigated the relationship between omega-3 and expression level of Tribbles in cumulus cells in vitro; however, to clarify the exact mechanism of omega-3 action on oocytes and cumulus cells, further research are required to reveal the effects of omega- 3 on expression level of genes and proteins associated with oocyte and cumulus cells maturation in vitro and in vivo.

\section{CONCLUSION}

In conclusion, the data obtained in the present study suggest that adding omega-3-acid ethyl ester to environment of oocyte and cumulus cells promotes maturation of live oocyte and cumulus cells in vitro which is accompanied by increasing of TRIB2 and decreasing of TRIB3 gene expression. It is suggested that supplementation of diet with omega-3 may improve the oocyte development in patients suffering failure in oocyte maturation.

\section{ACKNOWLEDGEMENT}

This paper has been extracted from the $\mathrm{PhD}$ dissertations in developmental biology approved and supported by Shiraz Branch, Islamic Azad University, Shiraz, Iran. We appreciate all who helped us to exert this research.

\section{REFERENCES}

Assidi M, Dieleman SJ, Sirard M-A. 2010. Cumulus cell gene expression following the LH surge in bovine preovulatory follicles: potential early markers of oocyte competence. REPRODUCTION. 140:835-852.

Bauer RC, Yenilmez BO, Rader DJ. 2015. Tribbles-1: a novel regulator of hepatic lipid metabolism in humans. Biochem Soc Trans. 43:1079-1084.

Brisard D, Chesnel F, Elis S, Desmarchais A, Sánchez-Lazo L, Chasles M, Maillard V, Uzbekova S. 2014. Tribbles expression in cumulus cells is related to oocyte maturation and fatty acid metabolism. J Ovarian Res. $7: 44$

Cao Y, Lu L, Liang J, Liu M, Li X, Sun R, Zheng Y, Zhang P. 2015. Omega-3 fatty acids and primary and secondary prevention of cardiovascular disease. Cell Biochem Biophys. 72:77-81.

Carro M, Buschiazzo J, Ríos GL, Oresti GM, Alberio RH. 2013. Linoleic acid stimulates neutral lipid accumulation in lipid droplets of maturing bovine oocytes. Theriogenology. 79:687-694.

Cheng Z, Abayasekara DRE, Ward F, Preece DMW, Raheem KA, Wathes DC. 2013. Altering $n-3$ to $n-6$ polyunsaturated fatty acid ratios affects prostaglandin production by ovine uterine endometrium. Anim Reprod Sci. 143:38-47.

Chiu YH, Karmon AE, Gaskins AJ, Arvizu M, Williams PL, Souter I, Rueda BR, Hauser R, Chavarro JE. 2018. Serum omega-3 fatty acids and treatment outcomes among women undergoing assisted reproduction. Hum Reprod. 33:156-165.

Dirandeh E, Towhidi A, Ansari Pirsaraei Z, Saberifar T, Akhlaghi A, Rezaei Roodbari A. 2015. The endometrial expression of prostaglandin cascade components in lactating dairy cows fed different polyunsaturated fatty acids. Theriogenology. 83:206-212.

Dugast E, Kiss-Toth E, Soulillou J-P, Brouard S, AshtonChess J. 2012. The tribbles-1 protein in humans: roles and functions in health and disease. Curr Mol Med. $13: 80-85$

Dunning KR, Cashman K, Russell DL, Thompson JG, Norman RJ, Robker RL. 2010. Beta-oxidation is essential for mouse oocyte developmental competence and early embryo development. Biol Reprod 83:909918.

Fayezi S, Leroy JLMR, Ghaffari Novin M, Darabi M. 2018. Oleic acid in the modulation of oocyte and preimplantation embryo development. Zygote. 26:1-13.

Gulliver CE, Friend MA, King BJ, Clayton EH. 2012. The role of omega-3 polyunsaturated fatty acids in reproduction of sheep and cattle. Anim Reprod Sci. 131:9-22.

Gumus E, Bulut HE, Kaloglu C. 2010. Cytoskeletal changes in oocytes and early embryos during in vitro fertilization process in mice. Anat Histol Embryol. 39:51-58.

Hernández-Montiel W, Collí-Dula RC, Ramón-Ugalde JP, Martínez-Núñez MA, Zamora-Bustillos R. 2019. RNAseq transcriptome analysis in ovarian tissue of pelibuey 
breed to explore the regulation of prolificacy. Genes (Basel). 10:358.

Jeromson S, Gallagher I, Galloway S, Hamilton D. 2015. Omega-3 fatty acids and skeletal muscle health. mar drugs.

Khalil WA, Marei WFA, Khalid M. 2013. Protective effects of antioxidants on linoleic acid-treated bovine oocytes during maturation and subsequent embryo development. Theriogenology. 80:161-168.

Kirkup SE, Cheng Z, Elmes M, Wathes DC, Abayasekara DRE. 2010. Polyunsaturated fatty acids modulate prostaglandin synthesis by ovine amnion cells in vitro. REPRODUCTION. 140:943-951.

Legault M-A, Tardif J-C, Dubé M-P. 2018. Pharmacogenomics of blood lipid regulation. Pharmacogenomics. 19:651-665.

Lirangi M, Meydani M, Zingg JM, Azzi A. 2012. $\alpha$ tocopheryl-phosphate regulation of gene expression in preadipocytes and adipocytes. BioFactors. 38:450-457.

Lohan F, Keeshan K. 2013. The functionally diverse roles of tribbles. Biochem Soc Trans. 41:1096-1100.

Lussier JG, Diouf MN, Lévesque V, Sirois J, Ndiaye K. 2017. Gene expression profiling of upregulated mRNAs in granulosa cells of bovine ovulatory follicles following stimulation with hCG. Reprod Biol Endocrinol. 15:88.

Mahla AS, Chaudhari RK, Verma AK, Singh AK, Singh SK, Singh G, Sarkar M, Dutta N, Kumar H, Krishnaswamy N. 2017. Effect of dietary supplementation of omega-3 polyunsaturated fatty acid (PUFA) rich fish oil on reproductive performance of the goat (Capra hircus). Theriogenology. 99:79-89.

Maillard V, Desmarchais A, Durcin M, Uzbekova S, Elis S. 2018. Docosahexaenoic acid (DHA) effects on proliferation and steroidogenesis of bovine granulosa cells. Reprod Biol Endocrinol. 16:40.

Marei WF, Wathes DC, Fouladi-Nashta AA. 2012. Differential effects of linoleic and alpha-linolenic fatty acids on spatial and temporal mitochondrial distribution and activity in bovine oocytes. Reprod Fertil Dev. 24:679.

Meher AP, Joshi AA, Joshi SR. 2013. Preconceptional omega-3 fatty acid supplementation on a micronutrientdeficient diet improves the reproductive cycle in Wistar rats. Reprod Fertil Dev. 25:1085.

Meng H, Shen Y, Shen J, Zhou F, Shen S, Das UN. 2013. Effect of n-3 and n-6 unsaturated fatty acids on prostate cancer (PC-3) and prostate epithelial (RWPE-1) cells in vitro. Lipids Health Dis. 12:160.

Mirabi P, Chaichi MJ, Esmaeilzadeh S, Ali Jorsaraei SG, Bijani A, Ehsani M, hashemi Karooee SF. 2017. The role of fatty acids on ICSI outcomes: a prospective cohort study. Lipids Health Dis. 16:18.

Nehra D, Le HD, Fallon EM, Carlson SJ, Woods D, White YA, Pan AH, Guo L, Rodig SJ, Tilly JL, et al. 2012. Prolonging the female reproductive lifespan and improving egg quality with dietary omega-3 fatty acids. Aging Cell. 11:1046-1054.

Nikoloff N, Pascua AM, Anchordoquy JM, Anchordoquy JP, Sirini MA, Seoane A, Furnus CC. 2017. Effect of eicosapentaenoic acid on bovine cumulus-oocyte complex in vitro. Cell Biol Int [Internet]. 41:505-513. Available from: http://doi.wiley.com/10.1002/cbin.10746

Nikseresht M. 2015. The nuclear maturation and embryo development of mice germinal vesicle oocytes with and without cumulus cell after vitrification. J Clin Diagnostic Res. 9:AF01-AF04.

Örd Tiit, Örd D, Adler P, Vilo J, Örd Tõnis. 2015. TRIB3 enhances cell viability during glucose deprivation in HEK293-derived cells by upregulating IGFBP2, a novel nutrient deficiency survival factor. Biochim Biophys Acta - Mol Cell Res. 1853:2492-2505.

Ortiz ME, Bühler MI, Zelarayán LI. 2014. Involvement of PLA 2 , COX and LOX in Rhinella arenarum oocyte maturation. Zygote. 22:440-445.

Oseikria M, Elis S, Maillard V, Corbin E, Uzbekova S. 2016. $\mathrm{N}-3$ polyunsaturated fatty acid DHA during IVM affected oocyte developmental competence in cattle. Theriogenology. 85:1625-1634.e2.

Safdar AHA, Sadeghi AA, Chamani M. 2017. Effects of different fat sources (saturated and unsaturated) on reproductive performance and biological indices of ewes during flushing period. Trop Anim Health Prod. 49:1447-1453.

Shaaker M, Rahimipour A, Nouri M, Khanaki K, Darabi M, Farzadi L, Shahnazi V, Mehdizadeh A. 2012. Fatty acid composition of human follicular fluid phospholipids and fertilization rate in assisted reproductive techniques. Iran Biomed J. 16:162-168.

Sirard M-A. 2011. Follicle environment and quality of in vitro matured oocytes. J Assist Reprod Genet. 28:483-488.

Veshkini A, Khadem AA, Mohammadi-Sangcheshmeh A, Alamouti AA, Soleimani M, Gastal EL. 2016. Linolenic acid improves oocyte developmental competence and decreases apoptosis of in vitro -produced blastocysts in goat. Zygote. 24:537-548.

Virant-Klun I, Knez K, Tomazevic T, Skutella T. 2013. Gene expression profiling of human oocytes developed and matured in vivo or in vitro. Biomed Res Int. 2013:1-20.

Wang L, Jing J, Fu Q, Tang X, Su L, Wu S, Li G, Zhou L. 2015. Association study of genetic variants at newly identified lipid gene TRIB1 with coronary heart disease in Chinese Han population. Lipids Health Dis. 14:46.

Wonnacott K, Kwong W, Hughes J, Salter A, Lea R, Garnsworthy P, Sinclair K. 2020. Dietary omega-3 and 6 polyunsaturated fatty acids affect the composition and development of sheep ranulose cells, oocytes and embryos. Reproduction. 139:57-69.

Wu S, Guo Y, Wu Y, Zhu S, He Z, Chen YQ. 2015. Omega-3 free fatty acids inhibit tamoxifen-induced cell apoptosis. Biochem Biophys Res Commun. 459:292-299. 
Zachut M, Dekel I, Lehrer H, Arieli A, Livshitz L, Yakoby S, Moallem U. 2010. Effects of dietary fats differing in $\mathrm{n}$ 6:n-3 ratio fed to high-yielding dairy cows on fatty acid composition of ovarian compartments, follicular status, and oocyte quality. J Dairy Sci. 93:529-545.

Zajdel A, Wilczok A, Chodurek E, Gruchlik A, Dzierzewicz Z. 2013. Polyunsaturated fatty acids inhibit melanoma cell growth in vitro. Acta Pol Pharm. 70:365-9.

Zhang W, Wu M, Kim T, Jariwala RH, Garvey WJ, Luo N, Kang M, Ma E, Tian L, Steverson D, et al. 2016.
Skeletal Muscle TRIB3 Mediates Glucose Toxicity in Diabetes and High- Fat Diet-Induced Insulin Resistance. Diabetes. 65:2380-2391.

Zhou C-J, Wu S-N, Shen J-P, Wang D-H, Kong X-W, Lu A, Li Y-J, Zhou H-X, Zhao Y-F, Liang C-G. 2016. The beneficial effects of cumulus cells and oocyte-cumulus cell gap junctions depends on oocyte maturation and fertilization methods in mice. PeerJ. 4:e1761. 